\title{
In silico Analysis Metabolic Pathways for Identification of Putative Drug Targets for Staphylococcus aureus
}

\author{
V. K. Morya*, Varun Dewaker, S. D. Mecarty and Raghuvir Singh
}

Department of Molecular and Cellular Engineering Jacob School of Biotechnology and Bioengineering Sam Higginbotom Institute of Agriculture, Technology \& Sciences, Allahabad, Uttar Pradesh, INDIA

\begin{abstract}
Staphylococcus aureus is one of the most important and studied gram positive bacterial strains, which have a great potential to infect human beings as well as other mammals. The hospital-acquired methicillin-resistant, vancomycinsusceptible gram-positive bacteria strain is responsible for much life threatening diseases like Toxic-shock syndrome, staphylococcal scarlet fever, meningitis, osteomyelitis, etc. This antibiotic resistance strain, lead to development of the new antibiotics or drug molecules which can kill or suppress the growth of Staphylococcus aureus. We have performed an insilico comparative analysis of metabolic pathways of the host Homo sapiens and the pathogen $S$. aureus. The e-value threshold cut-off was set to 0.005 . We have identified total 235 enzyme sequences, which are non homologous to Homo sapiens protein sequences and among them 59 enzymes are found to be essential for survival of the $S$. aureus according to the DEG database. Further PA-SUB analysis Results showed that about $52.5 \%$ enzymes are found to be in the cytoplasm, $13.5 \%$ enzymes are found to be in extracellular, $6.7 \%$ enzymes are plasma membrane protein and $27.1 \%$ enzymes are given no positive prediction. In this comparative analysis, we have also found 5 unique pathways among 59 essential and 23 non homologous enzymes.
\end{abstract}

Keywords: Staphylococcus aureus; Drug targeting; Pathway analysis; DEG; PA-SUB

\section{Introduction}

Staphylococcus aureus a member of Staphylococcacea is considered as an opportunistic pathogen for the different mammals including Livestock as well as humans (Lowy, 1998; Projan and Novick, 1997). It has been reported that Staphylococcus aureus is resistance against varies antibiotics present in the market (Lowy, 1998; Walsh and Bowe, 2002). This bacterial strain world widely known for causing many of the severe and deadly diseases like osteomyelitis, bacteremia, endocarditis, meningitis, Scalded Skin Syndrome, Toxic Shock Syndrome, food poisoning, etc. (Lowy, 1998; Diekema et al., 2001). It is the primary cause of lower respiratory tract infections and surgical site infections (Richards et al., 1999) and the second leading cause of nosocomial bacteremia (Wisplinghoff et al., 2004), pneumonia, and cardiovascular infections (Richards et al., 1999). Besides these diseases, it also found on the skin of the human beings and causing major problems like pimple, sour throat, hair follicle infection, acne, and sties (a sty is an inflammation of a gland in the eyelid). It also causes boils, which are deeper pus-filled abscesses of the skin and underlying tissue (Freeman-cook and Freeman-cook, 2006; Carleton et al., 2004; King et al., 2006). In common with other facultative aerobes, $S$. aureus can grow in the absence of oxygen either by fermentation or by using an alternative terminal electron acceptor, such as nitrate. Various studies suggest that oxygen plays a role in the pathogenesis of $S$. aureus, in both its capacity to produce virulence factors and its ability to persist and grow in different and often hostile environmental niches (Chan and Foster, 1998; Clements and Foster, 1999; Kass et al., 1987; Ohlsen et al., 1997; Ross and Onderdonk, 2000; Yarwood and Schlievert, 2000). The bacteria contain or can produce a variety virulence factor like adhesion, colonization, exoenzyme and exotoxins, capsule, etc. These virulence factors help the bacteria to attach to the host cells, it can bind to proteins such as fibronectin, laminin, vitronectin, and collagen, which form the extracellular matrix of epithelial and endothelial surfaces (Gillaspy et al., 1998; Freeman-cook and Freeman-cook, 2006). The resistance to antibiotics emerged and spread rapidly among strains of $S$. aureus. About $90 \%$ of S. aureus strains are currently resistant to penicillin and derivatives. To combat this problem, new derivatives of penicillin were introduced (Lowy, 2003; Freeman-cook and Freemancook, 2006). Today, around $50 \%$ of all $S$. aureus infections are multidrug resistant (resistant to penicillin, methicillin, tetracycline, and erythromycin). One antibiotic stood for years as a drug that did not cause resistant bacteria to emerge. It often thought of as a drug of "last resort," the name implies exactly how it has been used. Thus, the battle between humans and bacteria continues (Freeman-cook and Freeman-cook, 2006). The computational approach has been used to investigate novel drug targets in other pathogenic organisms such as Pseudomonas aeruginosa (Sakharkar et al., 2004; Perumal et al., 2007) and in Helicobacter pylori (Dutta et al., 2006). As most currently known, antibacterial are essentially inhibitors of certain bacterial enzymes, all enzymes specific to bacteria can be considered as potential drug targets (Michael and Eugene, 1999). In this study, we have adopted a strategy for comparative metabolic pathway analysis to find out some potential targets against $S$. aureus. Only those enzymes which show unique properties than the host were selected as the target.

\section{Materials and Method}

Identification of potential drug targets

KEGG (Kanehisa et al., 2002) pathway database was used as a source

*Corresponding author: V. K. Morya, Assistant Professor, Department of Molecular and Cellular Engineering, Jacob School of Biotechnology and Bioengineering, Sam Higginbotom Institute of Agriculture, Technology \& Sciences, Allahabad, Uttar Pradesh, INDIA, Tel: 91-9918002900, E-mail: vivekmorya@rediffmail.com

Received May 31, 2010; Accepted June 10, 2010; Published June 10, 2010

Citation: Morya VK, Dewaker V, Mecarty SD, Singh R (2010) In silico Analysis Metabolic Pathways for Identification of Putative Drug Targets for Staphylococcus aureus. J Comput Sci Syst Biol 3: 062-069. doi:10.4172/jcsb.1000058

Copyright: (c) 2010 Morya VK, et al. This is an open-access article distributed under the terms of the Creative Commons Attribution License,which permits unrestricted use, distribution, and reproduction in any medium, provided the original author and source are credited. 
Citation: Morya VK, Dewaker V, Mecarty SD, Singh R (2010) In silico Analysis Metabolic Pathways for Identification of Putative Drug Targets for Staphylococcus aureus. J Comput Sci Syst Biol 3: 062-069. doi:10.4172/jcsb.1000058

\begin{tabular}{|c|c|c|c|}
\hline SI. No. & Target Enzyme/s & Pathways in which the target is/are involved & length \\
\hline 1 & PTS system, glucose-specific enzyme II, A component (EC:2.7.1.69) GI: 15927003 & 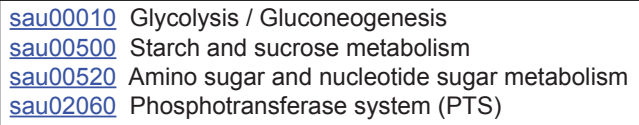 & 166 aа \\
\hline 2 & fructose specific permease (EC:2.7.1.69) fruA GI: $\underline{15926377}$ & $\begin{array}{l}\underline{\text { sau00051 }} \begin{array}{l}\text { Fructose and mannose metabolism } \\
\underline{\text { sau01100 }} \\
\text { sau02060 }\end{array} \text { Phosphotic pathways } \\
\end{array}$ & 652 aa \\
\hline 3 & mannitol-1-phosphate 5-dehydrogenase (EC:1.1.1.17) Gl: $\underline{15927740}$ & 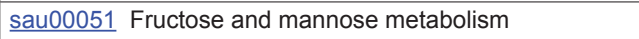 & 368 aа \\
\hline 4 & galactose-6-phosphate isomerase subunit LacA (EC: $\underline{5.3 .1 .26}) \mathrm{Gl}: \underline{15927775}$ & sau00052 Galactose metabolism & 142 aa \\
\hline 5 & tagatose-6-phosphate kinase (EC:2.7.1.144) lacC GI: 15927773 & $\underline{\text { sau00052 }}$ Galactose metabolism & 310 aa \\
\hline 6 & Phosphotransacetylase (EC: $\underline{2.3 .1 .8}$ ) eutD GI: 15926266 & $\begin{array}{l}\underline{\text { sau00430 }} \begin{array}{l}\text { Taurine and hypotaurine metabolism } \\
\text { sau00620 }\end{array} \text { Pyruvate metabolism } \\
\underline{\text { sau00640 }} \text { Propanoate metabolism }\end{array}$ & 328 aa \\
\hline 7 & F0F1 ATP synthase subunit B (EC:3.6.3.14) atpF GI: $\underline{15927681}$ & $\begin{array}{l}\text { sau00190 Oxidative phosphorylation } \\
\underline{\text { sau01100 }} \text { Metabolic pathways }\end{array}$ & 173 aа \\
\hline 8 & respiratory nitrate reductase alpha chain (EC:1.7.99.4) narG GI: $\underline{15927975}$ & $\begin{array}{l}\underline{\text { sau00910 Nitrogen metabolism }} \\
\underline{\text { sau02020 }} \text { Two-component system }\end{array}$ & 1229 aа \\
\hline 9 & UDP-N-acetylglucosamine 1-carboxyvinyltransferase (EC: $\underline{2.5 .1 .7)}$ murA GI: 15927674 & $\begin{array}{l}\underline{\text { sau00520 Amino sugar and nucleotide sugar metabolism }} \\
\underline{\underline{\text { sau00550 }}} \text { Peptidoglycan biosynthesis } \\
\underline{\text { sau01100 }} \text { Metabolic pathways }\end{array}$ & 421 aa \\
\hline 10 & UDP-N-acetylglucosamine 1-carboxyvinyltransferase (EC: $\underline{2.5 .1 .7)}$ murZ GI: 15927698 & $\begin{array}{l}\underline{\text { sau00520 Amino sugar and nucleotide sugar metabolism }} \\
\underline{\text { sau00550 }} \text { Peptidoglycan biosynthesis } \\
\underline{\text { sau01100 }} \text { Metabolic pathways }\end{array}$ & 419 aа \\
\hline 11 & UDP-N-acetylmuramate--L-alanine ligase (EC: $\underline{6.3 .2 .8})$ murC GI: 15927317 & 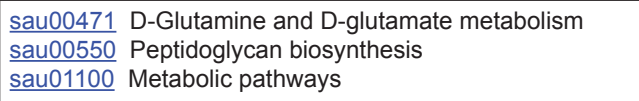 & 437 aа \\
\hline 12 & $\begin{array}{l}\text { UDP-N-acetylmuramoyl-L-alanyl-D-glutamate synthetase (EC: } \underline{6.3 .2 .9}) \text { murD } \\
\text { GI: } \underline{15926766}\end{array}$ & 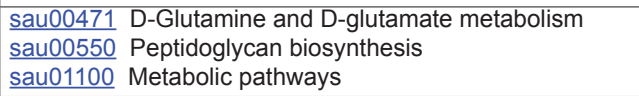 & 449 aа \\
\hline 13 & $\begin{array}{l}\text { UDP-N-acetylmuramoylalanyl-D-glutamyl-2,6-diaminopimelate-D-alanyl-D-alanyl } \\
\text { ligase; (EC: } \underline{6.3 .2 .10} \text { ) murF GI: } \underline{15927657}\end{array}$ & $\begin{array}{l}\underline{\text { sau00300 }} \text { Lysine biosynthesis } \\
\underline{\underline{\text { sau00550 }}} \text { Peptidoglycan biosynthesis } \\
\underline{\text { sau01100 }} \text { Metabolic pathways }\end{array}$ & 452 aa \\
\hline 14 & FmhB protein (EC:2.3.2.-) fmhB GI: 15927842 & $\begin{array}{l}\text { sau00550 Peptidoglycan biosynthesis } \\
\text { sau01100 Metabolic pathways }\end{array}$ & 421 aa \\
\hline 15 & $\begin{array}{l}\text { factor essential for expression of methicillin resistancefemA; (EC:2.3.2.-) } \\
\text { GI: } 15926954\end{array}$ & $\begin{array}{l}\underline{\text { sau00550 }} \text { Peptidoglycan biosynthesis } \\
\text { sau01100 Metabolic pathways }\end{array}$ & 420 aa \\
\hline 16 & FemB protein (EC:ㄹ.3.2.-) femB Gl: 15926955 & $\begin{array}{l}\underline{\text { sau00550 }} \text { Peptidoglycan biosynthesis } \\
\underline{\text { sau01100 }} \text { Metabolic pathways }\end{array}$ & 419 aa \\
\hline 17 & D-alanyl-alanine synthetase A (EC: $\underline{6.3 .2 .4}$ ) ddl PDB: $\underline{2187} \underline{2180} \underline{218 \mathrm{C}} \mathrm{Gl}: \underline{15927658}$ & $\begin{array}{l}\underline{\text { sau00473 }} \text { D-Alanine metabolism } \\
\underline{\text { sau00550 }} \text { Peptidoglycan biosynthesis }\end{array}$ & 356 aa \\
\hline 18 & phosphoenolpyruvate-protein phosphatase (EC:2.7.3.9) ptsI GI: 15926670 & sau02060 Phosphotransferase system (PTS) & 572 aа \\
\hline 19 & $\begin{array}{l}\text { PTS system, N-acetylglucosamine-specific IIABC component (EC:2.7.1.69) ptaA } \\
\text { GI: } 15927303\end{array}$ & $\begin{array}{l}\underline{\text { sau00520 Amino sugar and nucleotide sugar metabolism }} \\
\underline{\text { sau02060 }} \text { Phosphotransferase system (PTS) }\end{array}$ & 488 aа \\
\hline 20 & PTS system, glucose-specific IIABC component ptsG GI: 15928117 & $\begin{array}{l}\underline{\text { sau00520 }} \text { Amino sugar and nucleotide sugar metabolism } \\
\text { sau02060 Phosphotransferase system (PTS) }\end{array}$ & 688 aа \\
\hline 21 & PTS system, mannitol specific IIA component mtIA GI: $\underline{15927739}$ & $\begin{array}{ll}\text { sau00051 } & \text { Fructose and mannose metabolism } \\
\text { sau02060 } & \text { Phosphotransferase system (PTS) }\end{array}$ & 144 aa \\
\hline 22 & preprotein translocase subunit SecY GI: $\underline{15927810}$ & $\underline{\text { sau03060 }} \begin{array}{l}\text { Protein export } \\
\text { sau03070 }\end{array}$ Bacterial secretion system & 430 aa \\
\hline 23 & preprotein translocase subunit SecA azi, div GI: 15926430 & $\begin{array}{ll}\underline{\text { sau03060 }} & \text { Protein export } \\
\underline{\text { sau03070 }} \text { Bacterial secretion system }\end{array}$ & 843 aa \\
\hline 24 & preprotein translocase subunit SecA azi, div GI: $\underline{15928235}$ & $\begin{array}{l}\text { sau03060 Protein export } \\
\text { sau03070 } \text { Bacterial secretion system }\end{array}$ & 796 aа \\
\hline 25 & glutamate racemase (EC: $\underline{5.1 .1 .3})$ murl GI: $\underline{15926734}$ & $\begin{array}{l}\underline{\text { sau00471 }} \text { D-Glutamine and D-glutamate metabolism } \\
\text { sau01100 Metabolic pathways }\end{array}$ & 266 aa \\
\hline 26 & DNA-directed RNA polymerase subunit alpha (EC: $\underline{2.7 .7 .6})$ rpoA GI: 15927804 & $\begin{array}{l}\underline{\text { sau00230 }} \text { Purine metabolism } \\
\underline{\text { sau00240 }} \text { Pyrimidine metabolism } \\
\underline{\underline{\text { sau01100 }}} \text { Metabolic pathways } \\
\underline{\text { sau03020 }} \text { RNA polymerase }\end{array}$ & 314 aa \\
\hline 27 & DNA polymerase III PolC (EC: $\underline{2.7 .7 .7)}$ polC GI: $\underline{15926847}$ & 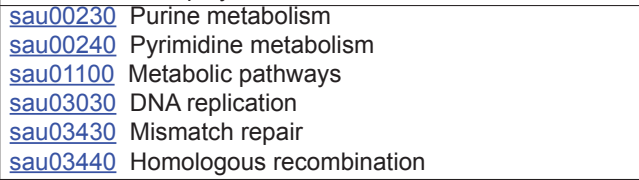 & 1438 aа \\
\hline 28 & tryptophan synthase subunit beta (EC: $\underline{4.2 .1 .20}$ ) trpB GI: 15926952 & $\begin{array}{l}\underline{\text { sau00260 Glycine, serine and threonine metabolism }} \\
\underline{\text { sau00400 }} \text { Phenylalanine, tyrosine and tryptophan } \\
\text { biosynthesis } \\
\underline{\text { sau01100 Metabolic pathways }}\end{array}$ & 404 aa \\
\hline
\end{tabular}




\begin{tabular}{|c|c|c|c|}
\hline 29 & urease subunit gamma (EC: $\underline{3.5 .1 .5})$ ureA GI: $\underline{15927868}$ & 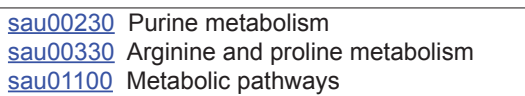 & 100 aa \\
\hline 30 & urease subunit beta (EC: $\underline{3.5 .1 .5})$ ureB $\mathrm{Gl}: \underline{15927869}$ & 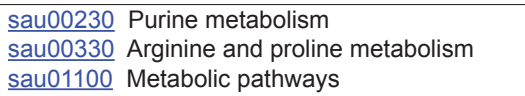 & 136 aа \\
\hline 31 & DNA polymerase III, alpha chain (EC: $\underline{2.7 .7 .7)}$ dnaE GI: 15927280 & $\begin{array}{ll}\underline{\text { sau00230 }} & \text { Purine metabolism } \\
\underline{\underline{\text { sau00240 }}} & \text { Pyrimidine metabolism } \\
\underline{\underline{\text { sau01100 }}} & \text { Metabolic pathways } \\
\underline{\text { sau03030 }} & \text { DNA replication } \\
\underline{\underline{\text { sau03430 }}} & \text { Mismatch repair } \\
\underline{\text { sau03440 }} & \text { Homologous recombination }\end{array}$ & 1065 aa \\
\hline 32 & replicative DNA helicase (EC:3.6.1.-) dnaC GI: 15925721 & sau03030 DNA replication & 466 aa \\
\hline 33 & DNA primase; (EC:2.7.7.-) dnaG GI: 15927142 & sau03030 DNA replication & 605 aa \\
\hline 34 & excinuclease ABC subunit C uvrC GI: 15926730 & sau03420 Nucleotide excision repair & 593 aa \\
\hline 35 & recombination protein F recF GI: $\underline{15925709}$ & $\overline{\text { sau03440 }}$ Homologous recombination & 370 aa \\
\hline 36 & PriA, primosomal protein (EC:3.6.1.-) priA GI: 15926795 & sau03440 Homologous recombination & 802 aa \\
\hline 37 & potassium-transporting ATPase subunit A (EC:3.6.3.12) kdpA, SCCmec GI: 29165619 & 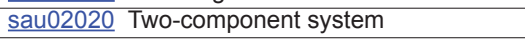 & 558 aa \\
\hline 38 & chromosomal replication initiation protein dnaA GI: 15925706 & 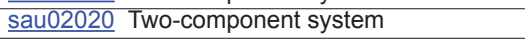 & 453 aа \\
\hline 39 & two-component sensor histidine kinase vraS GI: 15927459 & sau02020 Two-component system & 374 aa \\
\hline 40 & 30S ribosomal protein S17; rpsQ GI: 15927821 & sau03010 Ribosome & 87 aa \\
\hline 41 & 50S ribosomal protein L18 rpIR GI: $15 \overline{5927814}$ &  & 119 aa \\
\hline 42 & 50S ribosomal protein L30 rpmD Gl: 15927812 & $\overline{\text { sau03010 Ribosome }}$ & 59 aa \\
\hline 43 & 30S ribosomal protein S4 rpsD GI: 15927296 & sau03010 Ribosome & 200 aa \\
\hline 44 & 50S ribosomal protein L10 rplJ Gl: $\overline{15926217}$ & $\overline{\text { sau03010 Ribosome }}$ & 166 aa \\
\hline 45 & 50S ribosomal protein L35 rpml GI: $\overline{15927258}$ & $\overline{\text { sau03010 Ribosome }}$ & 66 aa \\
\hline 46 & 50S ribosomal protein L31 type B rpmE2 GI: 15927694 & sau03010 Ribosome & 84 aa \\
\hline 47 & 50S ribosomal protein L9 rpll Gl: 15925720 & $\overline{\text { sau03010 Ribosome }}$ & 148 aа \\
\hline 48 & 30S ribosomal protein S6 rpsF GI: 15926066 & sau03010 Ribosome & 98 aа \\
\hline 49 & 50S ribosomal protein L28 rpmB GI: 15926807 & sau03010 Ribosome & 62 aa \\
\hline 50 & 50S ribosomal protein L21 rplU GI: $\underline{15927227}$ & $\underline{\text { sau03010 Ribosome }}$ & 102 aa \\
\hline 51 & 30S ribosomal protein S20 rpsT GI: 15927166 & sau03010 Ribosome & 83 aа \\
\hline 52 & Phosphopentomutase (EC: $\underline{5.4 .2 .7}) \mathrm{drm}$ GI: $\underline{15925843}$ & $\begin{array}{l}\text { sau00030 Pentose phosphate pathway } \\
\underline{\text { sau00230 }} \text { Purine metabolism }\end{array}$ & 392 aа \\
\hline 53 & acetate kinase (EC:2.7.2.1) ackA GI: 15927288 & $\begin{array}{l}\underline{\text { sau00430 }} \text { Taurine and hypotaurine metabolism } \\
\underline{\text { sau00620 }} \text { Pyruvate metabolism } \\
\underline{\text { sau00640 }} \text { Propanoate metabolism } \\
\underline{\text { sau01100 }} \text { Metabolic pathways }\end{array}$ & 400 aа \\
\hline 54 & Undecaprenyl pyrophosphate phosphatase (EC: $\underline{3.6 .1 .27)}$ uppP GI: 15926360 & sau00550 Peptidoglycan biosynthesis & 291 aa \\
\hline 55 & PTS system, arbutin-like IIBC component glvC GI: 15927903 & $\begin{array}{l}\underline{\text { sau00010 }} \text { Glycolysis / Gluconeogenesis } \\
\underline{\text { sau02060 Phosphotransferase system (PTS) }}\end{array}$ & 534 aа \\
\hline 56 & preprotein translocase subunit SecY GI: 15928239 & $\begin{array}{l}\text { sau03060 Protein export } \\
\underline{\text { sau03070 }} \text { Bacterial secretion system }\end{array}$ & 403 aа \\
\hline 57 & potassium-transporting ATPase subunit A (EC:3.6.3.12) kdpA GI: 15927652 & sau02020 Two-component system & 558 aa \\
\hline 58 & 50S ribosomal protein L29 rpmC GI: 15927822 & sau03010 Ribosome & 69 aa \\
\hline 59 & 50S ribosomal protein L33 rpmG GI: 15927131 & sau03010 Ribosome & 49 aа \\
\hline
\end{tabular}

Table 1: Essential enzymes for survival of $S$. aureus, (Identified from DEG analysis)

of metabolic pathway information. Metabolic pathway identification numbers of the host $H$. sapiens and the pathogen Staphylococcus aureus was extracted from the KEGG database. Pathways which do not appear in the host but present in the pathogen according to KEGG database annotation have been identified as pathways unique to Staphylococcus aureus as in comparison to the host $H$. sapiens. Enzymes in these unique pathways as well as enzymes involved in other metabolic pathways under carbohydrate metabolism, amino acid metabolism, lipid metabolism, energy metabolism, vitamin and cofactor biosynthesis and nucleotide metabolism were identified from the KEGG database. The corresponding protein sequences were retrieved from the KEGG database. They were subjected to a BLASTp (Altschul et al., 1997) search against the non-redundant database with the e-value inclusion threshold set to 0.005 . The search was restricted to proteins from $H$. sapiens through an option available in the BLAST program, which allows the user to select the organism to which the search should be restricted. In the current context, the objective is to find only those targets, which do not have detectable human homologues. Enzymes, which do not have hits below the e-value inclusion threshold of 0.005 , were picked out as potential drug targets.

\section{Finding the essential targets}

The targets from the unique pathways were also subjected to a cluster of orthologous groups (COGS) search to identify homologues in other pathogens. After pBLAST analysis the 235 nonhomologous enzymes were further analysed for essentiality to pathogen by DEG database (http://tubic.tju.edu.cn/deg/). Essential genes are those indispensable for the survival of an organism, and their functions are therefore, considered a foundation of life (Zhang et al., 2004). 59 enzymes out of 235 from different pathways were found to be essential. These imperative 59 enzymes were submitted in Drug Bank database against approve drug targets and small molecules legends.

\section{Finding of biological significance of the targets}

For biological significance and distribution of these essential targets were analysed by PA-SUB (Proteome Analyst Specialized Sub Cellular Localization) Server v2.5 (Lu et al., 2004). This is required to find out the surface membrane proteins which could be probable vaccine targets.

\section{Results and Discussion}

From KEGG server all pathways associated with $S$. aureus have 


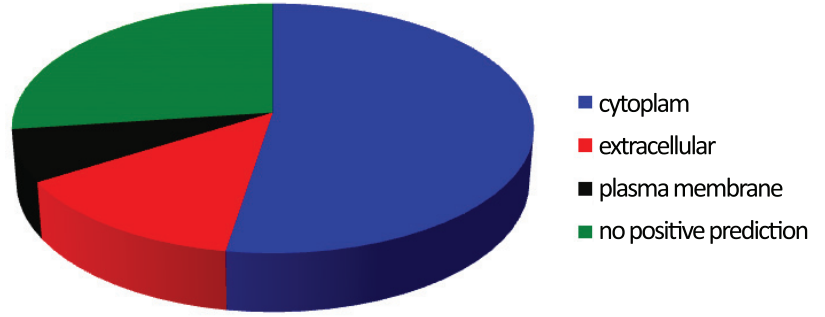

Figure 1: Pi diagram showing percentage distribution of putative targets in the cellular component.

been extensively analyzed and each of enzymes of pathways was compared with proteins from the host Homo sapiens, by performing a BLASTp search against the non-redundant database restricted to the $H$. sapiens subset. The e-value threshold cutoff was set to 0.005 to remove homologous sequence. Total 235 enzymes were identified as non-homologous to Human protein sequences. Design and targeting inhibitors against these non-homologous sequences could be the better approach for generation of new drugs. As it has reported in various texts that there are two types of enzymes or pathways are found in any living system i.e. dispensable and indispensable. Any dispensable or non-essential pathway or enzyme can't be a good choice as a drug target. Thus these 235 enzymes were further analysed with DEG server and considered cutoff score was $>100$ to enhance the specificity of enzyme in $S$. aureus. Total 59 enzymes out of all were found to be essential for $S$. aureus life cycle (Table 1). These targets were found to be potential targets and could be considered for rational drug design. Using metabolic pathway information as the starting point for the identification of potential targets has its advantages as each step in the pathway is validated as the essential function for the survival of the bacterium. The sub cellular localization analysis of all supposed essential and unique enzymes of Staphylococcus aureus were evaluated by PA-SUB server. As it was suggested that membrane associated protein could be the better target for developing vaccines. After analysis 31 proteins were found to be located in the cytoplasm, 8 as extra cellular, 4 on plasma membrane while 16 without any positive prediction (Figure 1 ).

Metabolic pathway analysis of the essential proteins in Staphylococcus aureus done by KEGG Automatic Annotation Server (KAAS). A result of comparative analysis of the metabolic pathways of the host and pathogen by using the Kyoto Encyclopedia of Genes and Genomes (KEGG) pathway database reveals some pathways that are unique to Staphylococcus aureus and are not present in the humans like D-Alanine metabolism, Peptidoglycan biosynthesis, Phosphotransferase system (PTS), Bacterial secretion system and Two-component system (Table 4). In addition to these pathways other pathways like streptomycin biosynthesis, novobiocin biosynthesis, C5-Branched dibasic acid metabolism and many other pathways are not present in humans, and some enzymes we found non homologous to human protein sequence, but they are not essential for survival of the $S$. aureus. Non homologous sequences from these pathways and other pathways are present in the 235 enzyme table as well as in the essential enzyme table. We again examined these unique pathways' enzymes' gene in the COGs (http://www.ncbi.nlm. nih.gov/COG/) to identify homologues in other pathogens. This COG id also can be shown from KEGG database (Table 4). Note that we are not considering the hypothetical or putative protein sequences (Table 2 and Table 3). This small group of proteins is required to be further verified for their role in Staphylococcus aureus survival and virulence by mutagenesis study. Further we analyze our essential enzymes of DEG database result against the drug bank database, and we identified about 8 approved drug target and 24 small molecule drug target (Table 2 and Table 3). The pathways and their enzyme and contribution were discussed bellow.

\section{Unique pathways : peptidoglycan biosynthesis}

All the bacterial species almost share a common feature of the cell wall which is helping them to maintain their structure as well as helping the bacterium to withstand tremendous internal pressure (up to $350 \mathrm{lbs} / \mathrm{cm}^{2}$ ) to keep the bacterial cell from exploding. The cell wall is composed of peptidoglycan, teichoic acids, and proteins (Schleifer, 1983). Chemical analysis of the cell wall indicates that more than $70 \%$ of the weight of the cell wall is peptidoglycan and that the teichoic acid is covalently bound to the peptidoglycan through a phosphodiester bond (Coley et al., 1978). Peptidoglycan is made of glycan chains of alternating $\mathrm{N}$-acetylglucosamine and $\mathrm{N}$-acetylmuramic acid cross-linked by short stem peptides attached to the N-acetylmuramic acid (Ghuysen, 1968, Schleifer and Kandler, 1972). However, the cells also must grow. For this to occur, the cell wall must enlarge. Various enzymes are required for this process. Enzymes called autolysis break the cross-links in the webbing of the cell wall, and enzymes called transpeptidases enlarge the cell wall and reseal it. Cell wall biosynthesis can be separated into two phases-the six intracellular enzymatic steps and the three steps that occur outside of the plasma membrane. Amongst the cytoplasmics steps involved in the biosynthesis of peptidoglycan, four ADP forming ligases (MurC, MurD, MurE and MurF) catalyze the assembly of its peptide moiety by successive additions of l-alanine, d-glutamate, a

\begin{tabular}{|c|c|c|c|c|}
\hline s.no. & Enzyme & Accession no & Drug bank target & score \\
\hline 1 & mannitol-1-phosphate 5-dehydrogenase & gi|15927740| & 4476 Mannitol dehydrogenase (DB00742) & 65 \\
\hline 2 & respiratory nitrate reductase alpha chain & gi|15927975| & 4344 Dimethyl sulfoxide/trimethylamine N-oxide reductase (DB01093) & 53 \\
\hline 3 & $\begin{array}{l}\text { UDP-N-acetylglucosamine } \\
\text { 1-carboxyvinyltransferase }\end{array}$ & gi|15927674| & 520 UDP-N-acetylglucosamine 1-carboxyvinyltransferase (DB00828) & 362 \\
\hline 4 & $\begin{array}{l}\text { UDP-N-acetylglucosamine } \\
\text { 1-carboxyvinyltransferase }\end{array}$ & gi|15927698| & 520 UDP-N-acetylglucosamine 1-carboxyvinyltransferase (DB00828) & 278 \\
\hline 5 & D-alanyl-alanine synthetase A & gi|15927658| & D-alanine--D-alanine ligase A (DB00260) & 298 \\
\hline 6 & DNA-directed RNA polymerase subunit alpha & gi|15927804| & DNA-directed RNA polymerase alpha chain (DB00615) & 242 \\
\hline 7 & $30 S$ ribosomal protein S4 & gi|15927296| & $\begin{array}{l}\text { 30S ribosomal protein S4 (DB00254; DB00256; DB00453; DB00560; } \\
\text { DB00595; DB00618; DB00759; DB01017) }\end{array}$ & 171 \\
\hline 8 & $50 S$ ribosomal protein $\mathrm{L} 10$ & gi|15926217| & $\begin{array}{l}\text { 50S ribosomal protein L10 (DB00254; DB00314; DB00446; DB00778; } \\
\text { DB00931; DB01190; DB01211; DB01321; } \\
\text { DB01627) }\end{array}$ & 102 \\
\hline
\end{tabular}

Table 2: Approved drug target identified by the drug bank server. 


\begin{tabular}{|c|c|c|c|c|}
\hline SI. No. & Enzyme name & Accession no & Drug bank target & score \\
\hline 1 & fructose specific permease & gi|15926377| & Nitrogen regulatory protein (DB03131) & 64 \\
\hline 2 & mannitol-1-phosphate5-dehydrogenase & gi|15927740| & Mannitol dehydrogenase (DB00742; DB01907) & 65 \\
\hline \multirow[t]{2}{*}{3} & galactose-6-phosphate isomerase subunit LacA & gi|15927775| & Sugar-phosphate isomerase (DB03661; DB03684) & 77 \\
\hline & & & Ribose-5-phosphate isomerase B (DB03108; DB04496) & 61 \\
\hline 4 & phosphotransacetylase & gi|15926266| & Phosphate acetyltransferase (DB02897) & 417 \\
\hline 5 & F0F1 ATP synthase subunit B & gi|15927681| & ATP synthase B chain (DB03091) & 59 \\
\hline \multirow[t]{2}{*}{6} & respiratory nitrate reductase alpha chain & gi|15927975 & Dimethyl sulfoxide reductase (DB02153; DB02379) & 59 \\
\hline & & & $\begin{array}{l}\text { Dimethyl sulfoxide/trimethylamine N-oxide reductase } \\
\text { (DB01093) }\end{array}$ & 53 \\
\hline \multirow[t]{3}{*}{7} & UDP-N-acetylglucosamine1-carboxyvinyltransferase & gi|15927674| & $\begin{array}{l}\text { UDP-N-acetylglucosamine1-carboxyvinyltransferase } \\
\text { (DB01867; DB01879; DB02435; DB02995; DB03089; } \\
\text { DB04174; DB04474) }\end{array}$ & 369 \\
\hline & & & $\begin{array}{l}2306 \text { UDP-N-acetylglucosamine1-carboxyvinyltransferase } \\
\text { (DB03397) }\end{array}$ & 362 \\
\hline & & & $\begin{array}{l}\text { UDP-N-acetylglucosamine1-carboxyvinyltransferase } \\
\text { (DB00828) }\end{array}$ & 362 \\
\hline \multirow[t]{3}{*}{8} & UDP-N-acetylglucosamine1-carboxyvinyltransferase & gi|15927698| & $\begin{array}{l}\text { UDP-N-acetylglucosamine1-carboxyvinyltransferase } \\
\text { (DB01867; DB01879; DB02435; DB02995; DB03089; } \\
\text { DB04174; DB04474) }\end{array}$ & 280 \\
\hline & & & $\begin{array}{l}\text { UDP-N-acetylglucosamine1-carboxyvinyltransferase } \\
\text { (DB03397) }\end{array}$ & 278 \\
\hline & & & $\begin{array}{l}\text { UDP-N-acetylglucosamine1-carboxyvinyltransferase } \\
\text { (DB00828) }\end{array}$ & 278 \\
\hline 9 & UDP-N-acetylmuramate--L-alanine ligase & gi|15927317| & $\begin{array}{l}\text { UDP-N-acetylmuramate--L-alanine ligase(DB01673; } \\
\text { DB03909; DB04395) }\end{array}$ & 152 \\
\hline 10 & $\begin{array}{l}\text { UDP-N-acetylmuramoyl-L-alanyl-D-glutamate } \\
\text { synthetase }\end{array}$ & gi|15926766| & $\begin{array}{l}\text { UDP-N-acetylmuramoylalanine--D-glutamate ligase } \\
\text { (DB01673; DB02314; DB03431; DB03801) }\end{array}$ & 179 \\
\hline 11 & $\begin{array}{l}\text { UDP-N-acetylmuramoylalanyl-D-glutamyl-2, } \\
\text { 6-diaminopimelate-D-alanyl-D-alanyl ligase }\end{array}$ & gi|15927657| & $\begin{array}{l}\text { UDP-N-acetylmuramoylalanine--D-glutamate ligase } \\
\text { (DB01673; DB02314; DB03431; DB03801) }\end{array}$ & 50 \\
\hline \multirow[t]{3}{*}{12} & D-alanyl-alanine synthetase $A$ & gi|15927658 & D-alanine--D-alanine ligase A (DB00260) & 298 \\
\hline & & & D-alanine--D-alanine ligase (DB03431 & 210 \\
\hline & & & D-alanine--D-alanine ligase B (DB03431) & 187 \\
\hline \multirow[t]{2}{*}{13} & phosphoenolpyruvate-protein phosphatase & gi|15926670| & Pyruvate, phosphate dikinase (DB02522) & 115 \\
\hline & & & Pyruvate, phosphate dikinase, chloroplast(DB01819) & 112 \\
\hline \multirow[t]{2}{*}{14} & preprotein translocase subunit SecA & gi|15926430| & Preprotein translocase subunit secA (DB03431) & 1036 \\
\hline & & & Preprotein translocase secA 1 subunit(DB03431) & 723 \\
\hline \multirow[t]{2}{*}{15} & preprotein translocase subunit SecA & gi|15928235| & Preprotein translocase subunit secA (DB03431) & 512 \\
\hline & & & Preprotein translocase secA 1 subunit(DB03431) & 440 \\
\hline 16 & glutamate racemase & gi|15926734| & Glutamate racemase (DB02174) & 164 \\
\hline 17 & DNA-directed RNA polymerase subunit alpha & $\mid$ gi|15927804| & DNA-directed RNA polymerase alpha chain(DB00615) & 242 \\
\hline 18 & DNA polymerase III PoIC & gi|15926847| & DNA polymerase III subunit epsilon (DB01643; DB01867) & 69 \\
\hline 19 & DNA primase & gi|15927142 & DNA primase (DB03166) & 244 \\
\hline 20 & chromosomal replication initiation protein & gi|15925706 & Chromosomal replication initiator protein dnaA(DB03431) & 213 \\
\hline 21 & 30 S ribosomal protein S4 & gi|15927296| & $\begin{array}{l}\text { 30S ribosomal protein S4 (DB00254; DB00256; DB00453; } \\
\text { DB00560; DB00595; DB00618; DB00759; DB01017) }\end{array}$ & 171 \\
\hline 22 & $50 S$ ribosomal protein L10 & gi|15926217| & $\begin{array}{l}\text { 50S ribosomal protein L10 (DB00254; DB00314; DB00446; } \\
\text { DB00778; DB00931; DB01190; DB01211; DB01321; } \\
\text { DB01627) }\end{array}$ & 102 \\
\hline 23 & 30 S ribosomal protein S6 & gi|15926066| & 30S ribosomal protein S6 (DB01867) & 53 \\
\hline 24 & acetate kinase & gi|15927288| & Acetate kinase (DB02423; DB03166; DB03431) & 374 \\
\hline
\end{tabular}

Table 3: Small molecule drug target evaluated by the drug bank server.

diamino acid (usually diaminopimelate or l-lysine) and d-alanine-dalanine to UDP N-acetylmuramic acid (Rogers et al., 1980; Van Heijenoort, 1994) among the enzyme involved in the peptidoglycan biosynthesis we found the total 9 enzyme (KAAS RESULT) in which murA, muC, murD, murF which are non homologous to Homo sapiens and homologous to other prokaryotes are essential for survival of $S$. aureus and ddl, uppP, femX, femA, femB so considering these gene/ gene product protein for inhibitor screening may also result from a good drug which can help in curing the disease caused by this microorganism.

\section{Phosphotransferase system (PTS)}

The phosphoenolpyruvate (PEP)-dependent phosphotransferase system (PTS) is a major mechanism used by bacteria for uptake of carbohydrates, particularly hexoses, hexitol, and disaccharides, where the source of energy is from PEP. The PTS consists of two general components, enzyme, I (EI) and histidine phosphocarrier protein (HPr), and of membrane-bound sugar specific permeases (enzymes II). Each enzyme II (EII) complex consists of one or two hydrophobic integral membrane domains (domains $C$ and D) and two hydrophilic domains (domains A and B). EII complexes may exist as distinct proteins or as a single multidomain protein. The PTS catalyzes the uptake of carbohydrates and their conversion into their respective phosphoesters during transport. There are four successive phosphoryl transfers in the PTS. Initial autophosphorylation of EI, using PEP as a substrate, is followed by transfer of the phosphoryl group from EI to HPr. EIIA catalyzes the self-phosphoryl transfer from $\mathrm{HPr}$ after which the phosphoryl group is transferred to histidine or cysteine residues of EIIB. The sugar is transported through the membrane-bound EIIC and is phosphorylated by the appropriate sugar-specific EIIB.The phosphoenolpyruvate (PEP)-dependent phosphotransferase system (PTS) is a major mechanism used by bacteria for uptake of carbohydrates, particularly hexoses, hexitols, and disaccharides, where the source of energy is from PEP. The PTS 


\begin{tabular}{|c|c|c|c|c|}
\hline Accession no. & Gene & Description & GI NUMBER & COG ID \\
\hline \multicolumn{5}{|c|}{ sau00473 D-Alanine metabolism } \\
\hline SA1887 & ddl & D-alanyl-alanine synthetase A & Gl: 15927658 & COG1181 \\
\hline \multicolumn{5}{|c|}{ sau00550 Peptidoglycan biosynthesis } \\
\hline SA1902 & murA & $\begin{array}{l}\text { UDP-N-acetylglucosamine } \\
\text { 1-carboxyvinyltransferase }\end{array}$ & GI: 15927674 & $\underline{\text { COG0766 }}$ \\
\hline SA1561 & murC & UDP-N-acetylmuramate--L-alanine ligase & GI: 15927317 & COG0773 \\
\hline SA1026 & murD & $\begin{array}{l}\text { UDP-N-acetylmuramoyl-L-alanyl-D-glutamate } \\
\text { synthetase }\end{array}$ & Gl: 15926766 & COG0771 \\
\hline SA1886 & murF & $\begin{array}{l}\text { UDP-N-acetylmuramoylalanyl-D-glutamyl-2,6- } \\
\text { diaminopimelate-D-alanyl-D-alanyl ligase }\end{array}$ & Gl: 15927657 & $\underline{\text { COG0770 }}$ \\
\hline SA1887 & ddl & D-alanyl-alanine synthetase A & Gl: 15927658 & COG1181 \\
\hline SA0638 & uppP & undecaprenyl pyrophosphate phosphatase & Gl: 15926360 & COG: COG1968 \\
\hline SA2057 & $\mathrm{fmhB}$ & FmhB protein & GI: 15927842 & COG: COG2348 \\
\hline SA1206 & femA & $\begin{array}{l}\text { factor essential for expression of methicillin } \\
\text { resistance }\end{array}$ & GI: 15926954 & $\underline{\operatorname{COG} 2348}$ \\
\hline SA1207 & femB & FemB protein & GI: 15926955 & COG: $\mathrm{COG} 2348$ \\
\hline \multicolumn{5}{|c|}{ sau02060 Phosphotransferase system (PTS) } \\
\hline SA0935 & ptsl & phosphoenolpyruvate-protein phosphatase & Gl: 15926670 & COG1080 \\
\hline SA1255 & Crr & $\begin{array}{l}\text { PTS system, glucose-specific enzyme II, A } \\
\text { component }\end{array}$ & GI: 15927003 & COG: $\underline{\operatorname{COG} 2190}$ \\
\hline SA0655 & fruA & fructose specific permease & GI: 15926377 & $\underline{\text { COG1445 }}$ \\
\hline SA1547 & ptaA & $\begin{array}{l}\text { PTS system, N-acetylglucosamine-specific } \\
\text { IIABC component }\end{array}$ & GI: 15927303 & COG: $\underline{\operatorname{COG} 2190}$ \\
\hline SA2326 & ptsG & $\begin{array}{l}\text { PTS system, glucose-specific IIABC } \\
\text { component }\end{array}$ & GI: 15928117 & COG: $\underline{\text { COG } 2190}$ \\
\hline SA1962 & $\mathrm{mtlA}$ & PTS system, mannitol specific IIA component & Gl: 15927739 & COG: $\mathrm{COG} 1762$ \\
\hline SA2114 & glvC & PTS system, arbutin-like IIBC component & GI: 15927903 & COG: $\mathrm{COG} 1263$ \\
\hline \multicolumn{5}{|c|}{ sau03070 Bacterial secretion system } \\
\hline SA2028 & SecY & preprotein translocase subunit & Gl: 15927810 & COG0201 \\
\hline SA2446 & SecY & preprotein translocase subunit & Gl: 15928239 & $\overline{\text { COG0201 }}$ \\
\hline SA0708 & secA, azi, div & preprotein translocase subunit SecA & GI: 15926430 & COG: $\mathrm{COG} 0653$ \\
\hline SA2442 & azi, div & preprotein translocase subunit SecA azi, div & GI: $\overline{15928235}$ & COG: $\overline{\mathrm{COG} 0653}$ \\
\hline \multicolumn{5}{|c|}{ sau02020 Two-component system } \\
\hline SA2185 & narG & respiratory nitrate reductase alpha chain & GI: 15927975 & COG0243 \\
\hline SA0068 & kdpA, SCCmec & potassium-transporting ATPase subunit A & GI: 29165619 & COG2060 \\
\hline SA0001 & dnaA & chromosomal replication initiation protein & GI: 15925706 & $\overline{\mathrm{COG0593}}$ \\
\hline SA1701 & vraS & two-component sensor histidine kinase & Gl: 15927459 & COG: COG4585 \\
\hline
\end{tabular}

Table 4: Information about Non-homologous enzymes from S. aureus searched against Homo sapience.

consists of two general components, enzyme, I (EI) and histidine phosphocarrier protein ( $\mathrm{HPr}$ ), and of membrane-bound sugar specific permeases (enzymes II). Each enzyme II (EII) complex consists of one or two hydrophobic integral membrane domains (domains $C$ and $D$ ) and two hydrophilic domains (domains A and B). EII complexes may exist as distinct proteins or as a single multidomain protein. The PTS catalyzes the uptake of carbohydrates and their conversion into their respective phosphoesters during transport. There are four successive phosphoryl transfers in the PTS. Initial autophosphorylation of EI, using PEP as a substrate, is followed by transfer of the phosphoryl group from EI to HPr. EIIA catalyzes the self-phosphoryl transfer from HPr after which the phosphoryl group is transferred to histidine or cysteine residues of EIIB. The sugar is transported through the membrane-bound EIIC and is phosphorylated by the appropriate sugar-specific EIIB. KAAS results showed that 7 enzymes were involving, which can be used as a potential drug target namely PTS system, glucose-specific enzyme II, A component, fructose specific permease, phosphoenolpyruvate-protein phosphatase, PTS system, $\mathrm{N}$-acetylglucosamine-specific IIABC component, PTS system, glucose-specific IIABC component. PTS system, mannitol specific IIA component mtlA. PTS system, arbutin-like IIBC component glvC.

\section{D-Alanine metabolism}

We find ddl D-alanyl-alanine synthetase. An enzyme and its pdb file is also available and is one of the essential enzymes, which is involved in both D-alanine metabolism as well as in peptidoglycan synthesis, d-Alanine is a necessary precursor in the bacterial peptidoglycan biosynthetic pathway. Thus targeting this enzyme will act on both the pathway.

\section{Bacterial secretion system}

Genomic analysis has revealed many novel potential targets for antimicrobial drugs and many of them are in essential and conserved metabolic pathways or cell-cell communication systems (Marraffini et al., 2006, Brown and Wright, 2005; Bassler and Losick, 2006). Such a potential mechanism which is necessary for the virulence of microbes is the bacterial secretion system. Pathogenic bacteria need virulence factors in order to infect their hosts and to survive the immune response. (Coombes et al., 2004; Finlay and McFadden, 2006) The secretion systems used for this purpose are in many cases very important or essential for bacterial virulence, and they are grouped into five classes according to their protein composition, amino acid similarities and mechanism.

Gram+ve bacteria secrete a wide range of proteins whose functions include biogenesis of organelles, such as pilli and flagella, nutrient acquisition, virulence, and efflux of drugs and other toxins. Six distinct secretion systems have been shown to mediate the protein export through the inner and outer membranes of Gram + ve bacteria. These pathways are highly conserved throughout the Gramnegative bacteria species.

In Gram-positive bacteria, secreted proteins are commonly 
translocated across the single membrane by the Sec pathway or the two-arginine (Tat) pathway. Type II secretion pathway supports the translocation of proteins associated with the virulence factors, across the outer membrane (Sandkvist, 2001). In our study, we identified 2 genes see, specific can be targeted for drug designing based on their role in the protein export and bacterial secretion system.

\section{Two-component system}

Two-component signal transduction systems, comprised of histidine kinases and their response regulator substrates, is the predominant means by which bacteria sense and respond to extracellular signals. These systems allow cells to adapt to prevailing conditions by modifying cellular physiology, including initiating programs of gene expression, catalyzing reactions, or modifying protein-protein interactions. These signaling pathways have also been demonstrated to play a role in coordinating bacterial cell cycle progression and development (Jeffrey et al., 2005). Two component systems, essential for the growth and survival in adverse environmental conditions, are ubiquitous in bacteria, and have been reported to be involved in virulence (Barrett and Hoch, 1998; Cai et al., 2005). In the prototypical two-component pathway, the sensor HK phosphorylates its own conserved. HIS residue in response to a signal(s) in the environment. Subsequently, the phosphoryl group of $\mathrm{HK}$ is transferred onto a specific Asp residue on the RR. The activated RR can then effect changes in cellular physiology, often by regulating gene expression. Two-component pathways thus eventually enable cells to sense and respond to stimuli by inducing changes in transcription. As they appear to be absent from metazoans, including humans, this class of molecules has been suggested as a major new target for antibacterial and antifungal drug development (Barrett and Hoch, 1998; Stephenson and Hoch, 2002). In this pathway, we found 4 enzymes which we can be used as a drug target namely respiratory nitrate reductase alpha chain narG (also involved in nitrogen metabolism), potassium-transporting ATPase subunit A $(\mathrm{kdpA}, \mathrm{SCCmec})$, chromosomal replication initiation protein dnaA and two-component sensor histidine kinase vraS.

\section{Conclusion}

Staphylococcus aureus has a circular chromosome and plasmid namely p with the number of nucleotides 2839469, 2614 protein genes as well as 79 RNA genes. In NCBI when we search Staphylococcus aureus in protein it shows that this subspecies contains about 6177 proteins. All the protein Staphylococcus aureus of that is nonhomologous to the human proteome could not be taken directly as targets as these also include a large number of proteins, which are not imperative for the viability of the organism. Therefore, these 236 non homologous sequences were subjected to BLASTP against DEG and 59 enzymes were identified essential with the total score cut off 100 or greater than 100 . In the list of DEG result enzymes are involved in Peptidoglycan biosynthesis, Phosphotransferase system (PTS), DNA replication, ribosome, mismatch repair, protein export and other many pathways. These identified putative targets may be exploiting further for developing drugs against $S$. aureus. It is quite obvious that increase of drug resistance properties requires more potential targets and by this Insilco approaches reduces the effort of wet lab and also increases the probability of success. By this present study we have tried to evaluate the targets could be better target fore rational drug designing.

\section{Acknowledgement}

Authors are thankful to Head, department of Molecular and Cellular Engineering, Sam Higginbotom Institute of Agriculture, Technology \& Sciences, Allahabad, for providing all kind of support.

\section{References}

1. Altschul SF, Thomas LM, Alejandro AS, Jinghui Z, Zheng Z, et al. (1997) Gapped BLAST and PSI BLAST: a new generation of protein database search programs. Nucleic Acids Res 17: 3389-3402.

2. Barrett JF, Hoch JA (1998) Two-component signal transduction as a target for microbial anti-infective therapy. Antimicrob Agents Chemother 42: 1529-1536.

3. Brown ED, Wright GD (2005) New Targets and Screening Approaches in Antimicrobial Drug Discovery Chem. Rev 105: 759-774.

4. Bassler BL, Losick R (2006) Bacterially Speaking. Cell 125: 237-246.

5. Chan PF, Foster SJ (1998) Role of SarA in virulence determinant production and environmental signal transduction in Staphylococcus aureus. J Bacteriol 180: $6232-6241$

6. Cai XH, Zhang Q, Shi SY, Ding DF (2005) Searching for potential drug targets in two-component and phosphorelay signal-transduction systems using threedimensional cluster analysis. Acta Biochim Biophys Sin 37: 293-302.

7. Clements MO, Foster SJ (1999) Stress resistance in Staphylococcus aureus Trends Microbiol 7: 458-462.

8. Carleton HA, Diep BA, Charlebois ED, Sensabaugh GF, Perdreau-Remington F (2004) Community-adapted methicillin-resistant Staphylococcus aureus (MRSA): population dynamics of an expanding community reservoir of MRSA $\mathrm{J}$ Infect Dis 190: 1730-1738.

9. Coombes BK, Valdez Y, Finlay BB (2004) Evasive Maneuvers by Secreted Bacterial Proteins to Avoid Innate Immune Responses. Curr Biol 14: R856.

10. Coley LE, Tarelli AR, Archibald A, Baddiley J (1978) The linkage between teichoic acid and peptidoglycan in bacterial cell wall. FEBS Lett 88: 1-9.

11. Dutta A, Singh SK, Ghosh P, Mukherjee R, Mitter S, et al. (2006) In silico identification of potential therapeutic targets in the human pathogen Helicobacter pylori . In Silico Biol 6: 0005.

12. Diekema DJ, Pfaller MA, Schmitz FJ (2001) Survey of infections due to Staphylococcus species: frequency of occurrence and antimicrobial susceptibility of isolates. collected in the SENTRY Antimicrobial Surveillance Program. Clin Infect Dis 32: S114-S132.

13. Finlay BB, McFadden G (2006) Anti-Immunology: Evasion of the Host Immune System by Bacterial and Viral Pathogens. Cell 124: 767.

14. Freeman-cook L, Freeman-cook K (2006) Staphylococcus Aureus Infections (Deadly Diseases and Epidemics). Chelsea House Publications.

15. Gillaspy AF, Lee CY, Sau S, Cheung AL, Smeltzer MS (1998) Factors affecting the collagen binding capacity of Staphylococcus aureus. Infect Immun 66: 3170-3178.

16. Ghuysen JM (1968) Use of bacteriolytic enzymes in determination of wall structure and their role in cell metabolism. Bacteriol Rev 32: 425-464.

17. Skerker JM, Prasol MS, Perchuk BS, Biondi EG, Laub MT (2005) TwoComponent Signal Transduction Pathways Regulating Growth and Cell Cycle Progression in a Bacterium: A System-Level Analysis. PLoS Biology 10: 17701772.

18. Kass EH, Kendrick MI, Tsai YC, Parsonnet J (1987) Interaction of magnesium ion, oxygen tension, and temperature in the production of toxic-shock-syndrome toxin-1 by Staphylococcus aureus. J Infect Dis 155: 812-815.

19. King MD, Humphrey BJ, Wang YF, Kourbatova EV, Ray SM, et al. (2006) Emergence of community-acquired methicillin-resistant Staphylococcus aureus USA 300 clone as the predominant cause of skin and soft-tissue infections. Ann Intern Med 144: 309-317.

20. Kanehisa M, Goto S, Kawashima S, Nakaya A (2002) The KEGG databases at Genome Net. Nucleic Acids Res 1: 42-46.

21. Lowy FD (1998) Staphylococcus aureus infections. N Engl J Med 339: 520 532.

22. Lowy FD (2003) Antimicrobial resistance: the example of Staphylococcus aureus. J Clin Invest 111: 1265-1273.

23. Lu Z, Szafron D, Greiner R, Lu P, Wishart DS (2004) Predicting Subcellular Localization of Proteins using Machine- Learned Classifiers. Bioinformatics 20: 547-556.

24. Michael YG, Eugene VK (1999) Searching for drug targets in microbial genomes. Curr Opin Biotechnol 10: 571-578. 
Citation: Morya VK, Dewaker V, Mecarty SD, Singh R (2010) In silico Analysis Metabolic Pathways for Identification of Putative Drug Targets for Staphylococcus aureus. J Comput Sci Syst Biol 3: 062-069. doi:10.4172/jcsb.1000058

25. Marraffini LA, Dedent AC, Schneewind O (2006) Sortases and the Art of Anchoring Proteins to the Envelopes of Gram-Positive Bacteria. Microbiol Mol Biol Rev 70: 192-221.

26. Ohlsen K, Koller KP, Hacker J (1997) Analysis of expression of the alpha-toxin gene (hla) of Staphylococcus aureus by using a chromosomally encoded hla::lacZ gene fusion. Infect Immun 65: 3606-3614.

27. Projan SL, Novick RP (1997) The molecular basis of virulence, p 55-81. In KB Cross and GL Archer (ed), Staphylococci in human disease. Churchill Livingstone, New York, NY.

28. Perumal D, Lim CS, Sakharkar KR, Sakharkar MK (2007) Differential genome analyses of metabolic enzymes in Pseudomonas aeruginosa for drug target identification. In Silico Biol 7: 453-465.

29. Ross RA, Onderdonk AB (2000) Production of toxic shock syndrome toxin 1 by Staphylococcus aureus requires both oxygen and carbon dioxide. Infect Immun 68: 5205-5209.

30. Richards MJ, Edwards JR, Culver DH, Gaynes RP (1999) Nosocomial infections in medical intensive care units in the United States. Crit Care Med 27: 887-92.

31. Rogers HT, Perkins HR, Ward JB (1980) Microbial Cell Walls and Membranes. Chapman and Hall Ltd, London, UK, pp 239- 297.

32. Sakharkar KR, Sakharkar MK, Chow VT (2004) A novel genomics approach for the identification of drug targets in pathogens, with special reference to Pseudomonas aeruginosa. In Silico Biol 4: 355-360.
33. Schleifer KH, Kandler O (1972) Peptidoglycan types of bacterial cell walls and their taxonomic implications. Bacteriol Rev 36: 407-477.

34. Schleifer KH (1983) The cell envelope in staphylococci and staphylococcal infections. In C S F Easmon and C Adlam (ed) Academic Press, London 2: 387428.

35. Sandkvist M (2001) Type II Secretion and Pathogenesis. Infect Immun 69 3523-3535.

36. Stephenson K, Hoch JA (2002) Two-component and phosphorelay signaltransduction systems as therapeutic targets. Curr Opin Pharmacol 2: 507-512.

37. Van Heijenoort J (1994) Biosynthesis of the peptidoglycan unit. In: Ghuysen JM, Hakenbeck, R (Eds), Bacterial Cell Wall Elsevier Science BV, Amsterdam 39-54.

38. Wisplinghoff H, Bischoff T, Tallent SM, Seifert H, Wenzel RP, et al. (2004) Nosocomial bloodstream infections in US hospitals: analysis of 24,179 cases from a prospective nationwide surveillancestudy. Clin Infect Dis 39: 309-317.

39. Walsh TR, Bowe RA (2002) The prevalence and mechanisms of vancomycin resistance in Staphylococcus aureus. Ann Rev Microbiol 56: 657-675.

40. Yarwood JM, Schlievert PM (2000) Oxygen and carbon dioxide regulation of toxic shock syndrome toxin 1 production by Staphylococcus aureus MN8. J Clin Microbiol 38: 1797-1803.

41. Zhang R, Ou HY, Zhang CT (2004) DEG: A database of essential genes Nucleic Acids Res 32: D271-D272. 